\title{
LEGAL DEVELOPMENT IN THE CONTEXT OF THE HUMANIZATION OF THE RUSSIAN LEGAL SYSTEM
}

\begin{abstract}
The subject of this research is Legal Development. The article discusses legal development in terms of the development of legal ideas about humanism by individual humans and society in general. Legal development includes human actions of intellectual and volitional nature mediated by the Law aimed at the transformation of elements of human activity (social reality). We are talking about humanization (spirituality and transformation of welfare) by means of human rights and society; the creation of a legal system, the center of which is a man, his rights and freedoms. Legal development is intellectual and volitional actions mediated by rights, aimed at the conversion and humanization of the legal system, the substantiation of the value of a person, one's rights and freedoms in the legal system. Research methodology is rational and critical thinking in the context of universal values, natural rights and freedoms of people. The novelty lies in translating the ideas of humanism in the Law, the transformation of the individual, society and the state in terms of legal ideas of human development by the individual and society. In law, the ideas of humanism are formed as a gradual change in the ratio of such concepts as 'rights' and 'man'. The idea lies in the 'humanization' of the Law, establishing such a legal system, which would be focused on people, their rights and freedoms.
\end{abstract}

Keywords: Development, legal development, modern legal system, human rights, human values, humanization, right values, rational thinking, critical thinking, person.

Аннотация: В статье рассматривается развитие правопонимания, как в рамках общества так и самим индивидом. Рассматривается процессу гуманизации права, а именно его трансформачии посредством закрепления основных прав и свобод человека. Таким образом, современная правовая система направлена на защиту прав человека и гражданина, а любые общественно значимые действия очениваются с точки зрения основных прав и свобод человека. В работе использовались классические методы научного исследования, наиболее часто используемые в юриспруденции. Среди них: методы анализа и синтеза, сравнительно-правовой метод и т.п.Новизна исследования заключается в демонстрации трансформации идей гуманизма в правовое поле. При этом отмечается трансформация под воздействие идей гуманизма не только права, но и самого общества, а также правосознания индивида. Таким образом, современное право фокусируется на человеке его правах и свободах.

Ключевые слова: Юриспруденция, гуманизм, право, современное право, правосознание, права человека, основные права, неотъемлемые права и свободы, рациональное сознание,человек.

lobal transformation in the contemporary world is caused by the rise of people in the legal sphere, and the humanization of social relations; it is increasingly perceived by legal scholars as a process of the formation of a new civilization, new ways of communication and activities, defining new goals, objectives and principles of relations between subjects ${ }^{1}$.

\footnotetext{
${ }^{1}$ Tarasov N.N. Methodological Problems of Modern Jurisprudence: Autoabstract-thesis of ... Doctor of Legal Sciences. Ekaterinburg, 2002. P. 2-3; Arkhipov S.I. Subject of Law (desk study): Autoabstract-thesis of ... Doctor of Legal Sciences. Ekaterinburg, 2005. P. 1-2; Puchkov O.A. Legal Anthropology and the Development of Science of State and Law (theoretical
}

Based on the fact that man and his natural rights and freedoms are at the heart of the changing legal world, jurisprudence must formulate qualitatively new approaches, and develop a fundamentally different view of the Law.

For humanism, the main thesis is the origin and development of human nature as a value, Man's place in reality, and the structure of the world of values; the man as the center of the world of values; the connection of different values with the social and cultural factors, as well as the structure of a person. The main category of the theory is the individual as

foundations): Autoabstract-thesis of ... Doctor of Legal Sciences. Ekaterinburg, 2002. P. 2-4. 
a value and universal values, i.e. the diversity of objects of human activities, public relations and natural phenomena within their range. They can act as 'substantive values', i.e. be evaluated in terms of good and evil, truth and untruth, beauty and ugliness, permissible and forbidden acts, just and unjust dealings, etc.

The embodiment of ideas about humanism in law is connected with legal development, as transformations carried out in Society, the State and the Law are the legal ideas of the development of humanism carried out by individuals and Society. In law, the ideas of humanism are formed as a gradual change in the ratio of the concepts of 'right' and 'man' concept. The idea lies in the 'humanization' of the Law, the establishment of such a legal system, which would focus on people, their rights and freedoms. ${ }^{2}$ Man, his rights and freedoms are the center of the transformation of the state, the Law, the legal system, law-making, law implementation, law enforcement, regulation, legal sources, the branches of the Law, and the legal process as a whole.

Legal development in the context of humanization of the legal system activates the dynamics of legal development. This context allows us to consider 'legal development' as a category, without which a shift in the ratio of the concepts of 'rights' and 'man' is impossible and unthinkable, and the general humanization of the legal system is problematic, since nothing happens by itself.

These transformations are not accidental. They allow the expansion of the level of theoretical vision of the legal development of the task, and they address issues, which would 'hardly be justified, if the consideration of humanitarian orientation of the legal theory was confined to the declaration of the general provisions alone. General declarations worth little. Especially, since they evidence the past of our social sciences, they can get along with an antihuman totalitarian approach to reality. ${ }^{3}$ Ideas of humanism, humanitarian and human values, and the man himself have ascended from possible to the granted through the rights and vaults of man and society.

In our opinion, both the humanization of the legal system, and the formation of a man, his rights and freedoms by the center of the legal system require certain actions aimed in this direction. Translating the idea of the humanization of the legal system, currently existing as legal possibilities to its natural implementation into legal reality requires researchers to justify and introduce such categories as 'legal development' to the scientific revolution.

\footnotetext{
${ }^{2}$ Perevalov V.D. Theory of State and Law: Textbook. Moscow, Vysshee obrazovanie Publ., 2005. P. 134.

${ }^{3}$ Alekseev S.S. Theory of Law. Moscow, BEK Publ., 1993. P. 24.
}

Legal science can offer a rational model of selforganization, and become a real tool for further philosophical and theoretical analysis of the right from the legal thinking to the legal development.

In the world of philosophical thought, the term 'development' has been used in many different interpretations throughout the centuries. Today we can talk about the peculiar history of its formation. Many thinkers of the past operated with this concept, and described its contents.

According to Democritus, development is associated with the unity of 'cosmos' and 'microcosm'. Here it is regarded as the goal of human existence. The aim would be reached, if the individual became adequate in his relation to the world as a result of own independence and activities to transform the world. Aristotle, on the contrary, put forward the 'ruling principle' (i.e. principle of subordination, hierarchy), which served as the theoretical and ideological basis for the conclusion about the constant expansion of human dominion over the world. ${ }^{4}$

With the emergence of axiology and the axiological aspect of philosophy and sociology in the twentieth century, the old idea of the subject who becomes familiar with himself and the world around him, which evolved into a philosophical, sociological and specifically scientific concept, acquired categorical status.

However, as a research topic in Domestic Law, the theory of legal development in the system of legal categories has not been studied.

The development of the natural environment and the medium of human activity directly or indirectly affects the rights and interests of an individual who is associated with the reproduction of spiritual and moral positives and values. Therefore, in the article, development is proposed as a form of human activity.

If this is a human activity, then the individual should occupy a central place, and play a leading role in the development. The development of vital human activity is mediated by right, which must embody the natural legal principles, universal benefits and values, and form and consolidate the legal interest in the sources of law in the form of spiritual and moral benefits for the individual and society. The formation of human interest as a spiritual and moral good actualizes the man himself as the center of any phenomenon and process; it actualizes the human qualities of person who is a conscious (intellectual and volitional) figure in the entire process of legal development.

The idea of development as a philosophical and general scientific category was formed substantially in the classical ${ }^{4}$ Aristotle. Writings in 4 volumes. Moscow, Mysl Publ., 1984. Vol.
4. P. 780-830. 


\section{Право и политика $3(183) \cdot 2015$}

era as a fundamental characteristic of the 'man-world' relation. The understanding of development as the mastering of the subject reproduced a world in which ownership, possession and power were core values of human existence.

In the current context of philosophical research, the category of 'development' is represented by two traditions: the first tradition views development as mastery of property and power (G-W-F. Hegel, K. Marx, M.K. Mamardashvili). ${ }^{5}$ The interpretation of development as the mastering of the subject is associated with the worldview, culture and practices of a particular type. 'Developed' in the context of 'ownership' reproduces the property, possession and power as total domination and the core value of human existence, and leads to the alienation of man from the outside world. The second tradition considers development in the human context as humanity, or the humanized process of development (M.S. Kagan, K.A. Svasyan, T.S. Karachentseva). ${ }^{6}$ It aims to overcome the alienation of man from the world around him; it is turned to the actual real individuals, who have been living forms of abstract existence, and self-spawning their own particular personality throughout their history.

The individual's development of the world (i.e. of elements of social reality) as that of a separate, particular personality, reveals a number of problems. They are associated with the category of development, its forms and methods. Most often, the category of 'development' is meaningfully interpreted as 'mastery'? This context of considering the problem leads to the fact that while the development of the world is identified with mastery of the world, philosophy reproduces an abstract universal subject.

The idea of 'Development', understood as 'mastery', was formed mainly in the philosophy of the classic era as a fundamental characteristic of the 'man-world' relation. In classical philosophy, the 'man-world' relation is an eternal, unchanging reality, a material, or ideal thing, to be mastered.

In the philosophical literature of the Soviet period, a thorough theoretical study of the problems of proving the worth of 'development' was carried out: it showed inconsistency of theoretical construction of such impersonal concepts as Society, History, the Absolute, Nation,

\footnotetext{
${ }^{5}$ Hegel G.W.F. Philosophy of Law. Moscow, Mysl Publ., 1990. 525 p.; Marx K. Economic Manuscripts of 1857 -1861: The initial version of "Capital" in two parts. Moscow, Politizdat Publ., 1986. P. 1. 564 p.; Mamardashvili M.K. Classical and non-classical ideal of rationality. Tbilisi, 1988.

${ }^{6}$ Kagan M.S. Human activity. Moscow, 1973; Svasyan K.A. Man as the creation and the creator of culture. Problems of Philosophy. 1987. No. 6; Karachentseva T.S. Man as a subject of world development // Social and philosophical problems of developing new territories: Collection of scientific papers. Tyumen, 1988. P. 25-31.
}

${ }^{7}$ Trubnikov N.N. Time of human existence. Moscow, 1987. P. 174-175.
Nationality, etc. ${ }^{8}$ In the monograph, M.K. Mamardashvili reconstructed the ontology of an intellectual and volitional entity that exists as an eternal, unchanging and infinite observer - an abstract universal being. For this subject, the world to be developed is presented in the form of an abstract universality, that is, it exists as nothing, belongs to nobody: it is foreign. To develop this world means to convert it from someone else's into your own, to master it and turn it into your own possession: that is, into the property subordinate to the power of an abstract universal subject. ${ }^{9}$

The social and cultural roots of the philosophy of ownership are transparent: it is a 'speculative expression' of abstract and universal communication created by equity and power over the things that have value, consisting exclusively of wealth, or 'the spirit of money'. 'The spirit of money' is regarded as a means of the abstract and general thinking that masters the abstract universal thing. ${ }^{10}$

The understanding of development as mastery of the subject is connected with an outlook, in which the world of ownership, possession, power and total domination is reproduced and recreated - i.e. the world of the core values of human existence. To change this understanding of development, we must overcome and transform the philosophy of property, power, wealth: the philosophy of abstract universal impersonality, that is. A man overcoming alienation is expressed in this concept. The impersonality of such general abstractions as 'humanity', 'society' and 'the absolute' as subjects of development can be overcome by the actualization and reproduction of a particular person his unique, free, sole human individuality, possessing the real specificity of a person. The transformation of abstract universal subjects of world development lies in the realization of humanity inherent in the process of development.

Philosophy, which considers a particular person as a precondition and a unique human personality, is recreated and reproduced as a truly human philosophy. To implement this idea, modern philosophy is forced to revise the traditional notions not only of the person but also of the world. In this world, which is a prerequisite for the existence of a person, for the fact that a person is alive and able to master, there is the only conclusion: the man-creator is a person of intellectual and volitional action.

Changes taking place in Russia called for the rethinking of the established ideas about the relationship between

\footnotetext{
${ }^{8}$ See, eg., works by Batischev G.S., Krutova O.N., Kuzmina T.A., Mozheeva A.K., Myslivchenko A.G. and others.

${ }^{9}$ Mamardashvili M.K. Classical and non-classical ideal of rationality. Tbilisi, 1988. P. 5-7.

${ }^{10}$ Marx K., Engels F. Collected Works. Vol. 42. P. 164.
} 
law and human rights. Such rethinking should respond to objectively ripened and objectively ongoing processes of the rise of an individual's position in society. The category of 'legal development' determines such a 'rise'.

Legal development includes human actions of an intellectual and volitional nature mediated by the right, aimed at the transformation of the elements of human activity (social reality). We are talking about humanization (spirituality and transformation of welfare) by means of human rights and society, the creation of such a legal system, in which a man and his rights and freedoms would always occupy a central place.

Legal development is intellectual rights and volitional action mediated by the right, aimed at conversion and humanization of the legal system, the substantiation of value of a person, his rights and freedoms, in the legal system.

Signs of legal development include:

- Intellectual and volitional human actions are the actualization of voluntary actions by means of human intelligence in accordance with spiritual and moral principles for the benefit of man and society, on the basis of self-existence, initiative and self-defense.

In the framework of the development, action is considered as deeds (action or inaction) of a person which involve his consciousness and will. In the context of the study, the man is considered as a bio-socio-spiritual being. Human actions must be mediated by the right. He (the man) performs the conversion, namely, through the legal means, legal instruments, self-existence, self-regulation and self-activity. These transformations are necessary for the person to indicate and justify his purpose in the legal system, create the basis of his legal self-existence, selfhood, ensure self-protection of rights, implement self-regulation and initiative, and gain access to justice.

- Actions aimed at transformation and humanization of the legal system lie in the fact that the natural law, human and intellectual beginnings and principles of human life and society are gradually embodied in the legal system.

- Intellectual and volitional actions mediated by the right are carried out in accordance with universal values. Human intelligence creates legal interest in the form of spiritual and moral principles. Legal interest in the context of this concept is the individual's intellectual view on how to use the spiritual and moral values, welfare and benefits properly for himself and for the society, or how to identify the purpose of the goods and values intellectually.

- Humanization (spiritualization and welfare-conversion) of the legal system is formed as a gradual change in the relation between the concepts of the 'right' and 'man'. This idea lies in the 'humanization' of the legal system, in creating such a legal system, which would focus on the individual, his rights and freedoms, and the state, law and their derivatives and processes must act as legal means and tools of the system.

In the social reality, under conditions of transition from a planned economy to a market economy, the basis of market farming is changing: the institutions of civil society are being revived, regulating the mechanism of social relations - all is changing. The admissible type of legal regulation becomes a priority, under which negative legal instruments are actively used (man, his natural rights, person, his legitimate interests, contracts, local, corporate and individual acts).

Legal development as a category exists for the determination of self-appointment of man's place and role in the legal system; the leading role belongs to decentralized legal regulation and sources of legal regulation of public relations.

The Declaration of the Rights and Freedoms of every man and citizen, the Constitution of the Russian Federation, the Civil Code, laws on property, citizenship and other regulations, all laid the foundation for the transformation of methods of legal regulation from imperative to discretionary and the predominance of a generally admissible type of regulation in human relations. There was a shift from imperative methods of legal regulation to dispositive ones, which resulted in the preponderance of the admissible type of regulation in human relations.

Changes in the legal regulation of social relations led to changes in the structure of modern sources of legal regulation. Reorientation of legal regulation from the primary use of state-centralized normative and legal means to the application of mainly contractual and legal means of regulation indicates that the Russian law is shifting the focus of its implementation forms from one source to another- more civilized.

In accordance with developments in the state and transformations in society, the legal development requires the mechanisms of legal regulation of social relations to be based primarily on individual contractual regulation, and only secondarily on state-legal regulation of social relations.

As a process of an individual's elevation in the right, legal development must organize its own relationships in the interests of man and society (e.g., regarding the application of labor and its organization and management) within the statutory framework. From this point of view, Chicherin was absolutely right when he wrote that, 'Contracts can serve the diverse interests of people, but the legal significance of these interests is obtained solely due to the fact that they are the subject of the agreement. Whatever may be the interest of a person in the actions of another person, one cannot demand 


\section{Право и политика $3(183) \cdot 2015$}

anything until an agreement is signed; on the other hand, when the decision has taken place, it is equally binding on the parties, whatever is the common interest. From a legal standpoint, the binding force of agreements requires two things: 1) for the will to be free; 2) for the will to be legitimate. This follows from the very concept of law, which is freedom."11

In order to humanize the legal regulation, legal development as a process of an individual's elevation in social reality, should be more widely considered in the sources of law. In a broad sense, we should not only consider the sources of law, but also the sources of legal regulation. Any form of the objectified expression of rights should be understood under the source of legal regulation, provided they are presented in the form of legal texts that gained legitimacy and therefore become legally significant rules of conduct for general, collective or individual values. ${ }^{12}$

In this world, which is a prerequisite for a person to exist, be alive and able to master, there is the only conclusion - man is the creator of elements of the world, the social reality of interpersonal interactions.

The human context of the idea of development served as the basis for the study of 'legal development' category in the system of legal theory categories. The category of 'legal development' is granted its independent nature and meaning as indirect human right to transform the social reality, for the right is created and transformed by an individual in the course of one's life.

The human context of the idea of development allowed the changing of the perception of the theory of law about an individual's place in the legal system, to justify the need for a category of 'legal development' for transforming on a moral and humanizing basis the Russian legal system from the post-Soviet to the legal system in the center of which there are human rights and freedoms. It actualized the man, provided the basis for changes in the individual's interest of right from the need to form it as spiritual and moral values to the incarnation of the human interest in the principles of natural law written into the Russian legal system.

A man and his natural rights and freedoms are the center of the transformation of society in the era of humanization. A particular individual possessing natural inalienable rights and freedoms sets specific goals, objectives and principles, and chooses the legal form of existence in order to achieve them. As part of scientific abstraction, we can argue that an individual chooses various organizations, including the state, delegating him part of their rights and responsibilities, deliberately restricting his own freedom in the hope they would protect the whole complex of his vital interests. In this sense, a man, his natural rights and freedoms are considered as the phenomena of civilization and culture. They are directly reflected in the processes of legal thinking, law-making, law implementation and law-enforcement.

At a certain stage of its evolution, legal development could change the very person. In contrast to the practice of law, which can be created, a man is a real phenomenon, since he objectively exists and operates. His legal actions are mediated by a sense of justice, legal culture, and finally, a legal interest and intellectual, strong-willed actions.

\section{Библиография:}

1. Tarasov N.N. Methodological Problems of Modern Jurisprudence: Autoabstract-thesis of ... Doctor of Legal Sciences. Ekaterinburg, 2002.

2. Arkhipov S.I. Subject of Law (desk study): Autoabstract-thesis of ... Doctor of Legal Sciences. Ekaterinburg, 2005.

3. Puchkov O.A. Legal Anthropology and the Development of Science of State and Law (theoretical foundations): Autoabstract-thesis of ... Doctor of Legal Sciences. Ekaterinburg, 2002.

4. Perevalov V.D. Theory of State and Law: Textbook. Moscow, Vysshee obrazovanie Publ., 2005.

5. Alekseev S.S. Theory of Law. Moscow, BEK Publ., 1993.

6. Hegel G.W.F. Philosophy of Law. Moscow, Mysl Publ., 1990. 525 p.

7. Marx K. Economic Manuscripts of 1857-1861: The initial version of "Capital" in two parts. Moscow, Politizdat Publ., 1986. P. 1. 564 p.

8. Mamardashvili M.K. Classical and non-classical ideal of rationality. Tbilisi, 1988.

9. Kagan M.S. Human activity. Moscow, 1973.

10. Svasyan K.A. Man as the creation and the creator of culture. Problems of Philosophy. 1987. No. 6.

11. Karachentseva T.S. Man as a subject of world development // Social and philosophical problems of developing new territories: Collection of scientific papers. Tyumen, 1988.

12. Trubnikov N.N. Time of human existence. Moscow, 1987.

${ }^{11}$ Chicherin B.N. Selected Works / Text preparation, drafting, introduction and commentary by A.V. Polyakova. Commentary on the "Philosophy of Right" by E.V. Timoshina and A.V. Polyakova. St. Petersburg, 1997. P. 96-97.

${ }^{12}$ Gorokhov B.A., Mavrin S.P., Khokhlov E.B. Sources of labor law and sources of legal regulation of social and labor relations // Pravovedenie. 2003. No. 6. P. 30-47. 
13. Chicherin B.N. Selected Works / Text preparation, drafting, introduction and commentary by A.V. Polyakova. Commentary on the "Philosophy of Right" by E.V. Timoshina and A.V. Polyakova. St. Petersburg, 1997.

14. Gorokhov B.A., Mavrin S.P., Khokhlov E.B. Sources of labor law and sources of legal regulation of social and labor relations // Pravovedenie. 2003. No. 6.

15. Мапельман В.М. «Гуманная педагогика» и гуманизм // NB: Педагогика и просвещение. - 2012. - № 2. - C.126-154. DOI: 10.7256/2306-4188.2012.2.360. URL: http://e-notabene.ru/pp/article_360.html

16. Н.С. Шиловская. Культурные смыслы гуманизма // Философия и культура. - 2013. - № 6. - С. 104-107. DOI: 10.7256/19992793.2013.6.6018

17. М.М. Прохоров. История, культура определения бытия и гуманизма // Философия и культура. - 2012. - № 2. - С. 104-107.

18. Е. Б. Рашковский. Культура и свобода (к проблематике Нового гуманизма) // Культура и искусство. - 2011. - № 2.

19. Щупленков О.В., Щупленков Н.О. Проблема формирования инновационной личности в современном обществе // NB: Психология и психотехника. - 2013. - № 8. - C.21-70. DOI: 10.7256/2306-0425.2013.8.10493. URL: http://e-notabene.ru/psp/article_10493.html

20. Цендровский О.Ю. Философия Антуана де Сент-Экзюпери: опыт реконструкции // NB: Филологические исследования. - 2013. - № 4. - C.1-33. DOI: 10.7256/2306-1596.2013.4.10651. URL: http://e-notabene.ru/fil/article_10651.html

21. Хорина Г.П. Демократия в современной российской культуре: идеал и реальность // NB: Культуры и искусства. -2013. - № 4. - C.1-15. DOI: 10.7256/2306-1618.2013.4.6973. URL: http://e-notabene.ru/ca/article_6973.html

22. Попов Е.А. Влияние постмодернизма на социоюридическую интерпретацию феномена современного гражданского общества // NB: Вопросы права и политики. - 2013. - № 1. - C.190-222. DOI: 10.7256/2305-9699.2013.1.461. URL: http://enotabene.ru/lr/article_461.htm

23. Gurevich, P. S. Will a human being stay unchanged? // Философия и культура. - 2013. - 2. - С. 261 - 262. DOI: 10.7256/19992793.2013.02.13.

\section{References (transliterated):}

1. Tarasov N.N. Methodological Problems of Modern Jurisprudence: Autoabstract-thesis of ... Doctor of Legal Sciences. Ekaterinburg, 2002.

2. Arkhipov S.I. Subject of Law (desk study): Autoabstract-thesis of ... Doctor of Legal Sciences. Ekaterinburg, 2005.

3. Puchkov O.A. Legal Anthropology and the Development of Science of State and Law (theoretical foundations): Autoabstract-thesis of ... Doctor of Legal Sciences. Ekaterinburg, 2002.

4. Perevalov V.D. Theory of State and Law: Textbook. Moscow, Vysshee obrazovanie Publ., 2005.

5. $\quad$ Alekseev S.S. Theory of Law. Moscow, BEK Publ., 1993.

6. Hegel G.W.F. Philosophy of Law. Moscow, Mysl Publ., 1990. 525 p.

7. Marx K. Economic Manuscripts of 1857-1861: The initial version of “Capital” in two parts. Moscow, Politizdat Publ., 1986. P. 1. 564 p.

8. Mamardashvili M.K. Classical and non-classical ideal of rationality. Tbilisi, 1988.

9. Kagan M.S. Human activity. Moscow, 1973.

10. Svasyan K.A. Man as the creation and the creator of culture. Problems of Philosophy. 1987. No. 6.

11. Karachentseva T.S. Man as a subject of world development // Social and philosophical problems of developing new territories: Collection of scientific papers. Tyumen, 1988.

12. Trubnikov N.N. Time of human existence. Moscow, 1987.

13. Chicherin B.N. Selected Works / Text preparation, drafting, introduction and commentary by A.V. Polyakova. Commentary on the "Philosophy of Right" by E.V. Timoshina and A.V. Polyakova. St. Petersburg, 1997.

14. Gorokhov B.A., Mavrin S.P., Khokhlov E.B. Sources of labor law and sources of legal regulation of social and labor relations // Pravovedenie. 2003. No. 6.

15. Mapel'man V.M. “Gumannaya pedagogika” i gumanizm // NB: Pedagogika i prosveshchenie. - 2012. - № 2. - S.126-154. DOI: 10.7256/2306-4188.2012.2.360. URL: http://e-notabene.ru/pp/article_360.html

16. N.S. Shilovskaya. Kul'turnye smysly gumanizma // Filosofiya i kul’tura. - 2013. - № 6. - S. 104-107. DOI: 10.7256/19992793.2013.6.6018

17. M.M. Prokhorov. Istoriya, kul’tura opredeleniya bytiya i gumanizma // Filosofiya i kul'tura. - 2012. - № 2. - S. 104-107.

18. E. B. Rashkovskii. Kul’tura i svoboda (k problematike Novogo gumanizma) // Kul'tura i iskusstvo. - 2011. - № 2.

19. Shchuplenkov O.V., Shchuplenkov N.O. Problema formirovaniya innovatsionnoi lichnosti v sovremennom obshchestve // NB: Psikhologiya i psikhotekhnika. - 2013. - № 8. - S.21-70. DOI: 10.7256/2306-0425.2013.8.10493. URL: http://e-notabene.ru/psp/ article_10493.html

20. Tsendrovskii O.Yu. Filosofiya Antuana de Sent-Ekzyuperi: opyt rekonstruktsii // NB: Filologicheskie issledovaniya. - 2013. № 4. - S.1-33. DOI: 10.7256/2306-1596.2013.4.10651. URL: http://e-notabene.ru/fil/article_10651.html

21. Khorina G.P. Demokratiya v sovremennoi rossiiskoi kul'ture: ideal i real'nost' // NB: Kul'tury i iskusstva. - 2013. - № 4. - S.1-15. DOI: 10.7256/2306-1618.2013.4.6973. URL: http://e-notabene.ru/ca/article_6973.html

22. Popov E.A. Vliyanie postmodernizma na sotsioyuridicheskuyu interpretatsiyu fenomena sovremennogo grazhdanskogo obshchestva // NB: Voprosy prava i politiki. -2013. - № 1.-S.190-222. DOI: 10.7256/2305-9699.2013.1.461. URL: http://e-notabene.ru/lr/article_461.htm

23. Gurevich, P. S. Will a human being stay unchanged? // Filosofiya i kul'tura. - 2013. - 2. - C. 261 - 262. DOI: 10.7256/19992793.2013.02.13. 